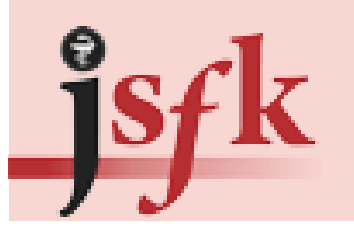

Jurnal Sains Farmasi \& Klinis (p-ISSN: 2407-7062 | e-ISSN: 2442-5435)

diterbitkan oleh Ikatan Apoteker Indonesia - Sumatera Barat homepage: http://jsfkonline.org

\title{
Pengaruh Konseling Obat Terhadap Pengetahuan dan Kepatuhan Pasien Congestive Heart Failure
}

\author{
(Influence of Drug Counseling on Knowledge and Compliance \\ of Patients With Congestive Heart Failure) \\ Elfia Neswita ${ }^{1 *}$, Dedy Almasdy ${ }^{1}$, Harisman $^{2}$ \\ ${ }^{\prime}$ Fakultas Farmasi, Universitas Andalas \\ ${ }^{2}$ IRNA Jantung RSUP DR. M. Djamil Padang
}

\begin{abstract}
Keywords:
drug counseling, $\mathrm{CHF}$, treatment adherence, pharmacy services

ABSTRACT: Compliance on therapy is a very important point in the successful treatment of CHF patients. However, such compliance is very low so do efforts to increase knowledge and treatment adherence through drug counseling by pharmacists. The design of this research was a quasi-experimental, one-group pretest-post-test design, with a population of CHF patients in IRNA Heart Hospital Dr. M. Djamil Padang in from March to December 2014. The sampling technique in the form of purposive sampling (50 patients) with questionnaires and interviews. Data analysis was performed using the Crosstab, Chi-Square, paired-sample t-test, Pearson Product Moment, simple linear regression, multiple linear regression and SPSS version 17. The results of this study indicate that the drug counseling significantly improve patient knowledge and compliance (97, 2\% and $77.6 \%(p<0.05))$.

Kata kunci: Konseling obat, CHF, kepatuhan terapi, pelayanan

kefarmasian

ABSTRAK: Kepatuhan terapi merupakan poin yang sangat penting dalam keberhasilan terapi pasien CHF. Namun, kepatuhan tersebut sangat rendah sehingga dilakukan upaya peningkatan pengetahuan dan kepatuhan terapi melalui konseling obat oleh farmasis. Rancangan jenis penelitian ini adalah quasi-eksperimental, one-group pretest-posttest design, dengan populasi pasien CHF di IRNA Jantung RSUP DR. M. Djamil Padang pada bulan Maret - Desember 2014. Teknik pengambilan sampel berupa purposive sampling (50 pasien) dengan kuesioner dan wawancara langsung. Analisis data dilakukan dengan menggunakan Crosstab, Chi-Square, Paired-sample T-test, Pearson Product Moment, regresi linier sederhana, regresi linear berganda dan SPSS versi 17. Hasil penelitian ini menunjukkan bahwa konseling obat secara signifikan meningkatkan pengetahuan dan kepatuhan pasien $(97,2 \%$ dan $77,6 \%(p<0,05))$.
\end{abstract}

\section{PENDAHULUAN}

Di Negara-negara maju dan berkembang, kematian yang diakibatkan oleh Penyakit Congestive Heart Failure (CHF) menduduki rangking pertama setiap tahun dan sepanjang tahun [1]. Sedangkan di Indonesia, penyakit jantung telah meningkat dan menjadi peringkat pertama sebagai penyebab utama kematian di Indonesia pada tahun 2000 dengan prevalensi pada orang di atas 15 tahun adalah 9,2\% [2]. Tingginya mortalitas, morbiditas dan biaya pada pasien jantung di rumah sakit rawat inap setiap tahun tidak kurang dari $8 \%$ [3]. Selain itu, pasien yang

\footnotetext{
*Corresponding Author: Elfia Neswita (Fakultas Farmasi Universitas Andalas, Kampus Limau Manis, Padang) email: elfianeswita@gmail.com
}

\section{Article History:}

Received: 20 Apr 2015

Published: 01 May 2016
Accepted: 18 Jun 2015

Available online: 15 Nov 2016 
dirawat inap sering mengalami permasalahan tidak konsistennya perawatan, banyaknya perubahan pada rejimen pengobatan, rendahnya pendidikan pasien [4] sehingga berpengaruh terhadap keberhasilan suatu pengobatan dan menyebabkan ketidakpatuhan terapi [5].

Manajemen terapi yang efektif menunjukkan penurunan angka eksaserbasi, rawat inap, dan angka kematian, serta peningkatan kualitas hidup pasien [6]. Kepatuhan terapi pasien merupakan salah satu isu penting dalam manajemen terapi yang menentukan efektivitas Akan tetapi, ketidakpatuhan pasien di negara-negara berkembang terhadap terapi jangka panjang pada penyakit kronis mencapai 50\% [7]. Hal tersebut menjadi masalah serius karena dapat meningkatkan perkembangan penyakit, memperburuk kondisi pasien, dan meningkatkan risiko komplikasi [8]. Oleh karena itu, perlu dilakukan upaya peningkatan kepatuhan terapi pasien.

Salah satu upaya yang dapat dilakukan adalah pemberian konseling obat yang menjadi bagian dari pelayanan kefarmasian (pharmaceutical care) [9,10]. Akan tetapi, hanya sedikit penelitian yang dilaporkan untuk mengevaluasi pengaruh konseling obat terhadap kepatuhan terapi pada pasien CHF [1]. Bertolak pada hal tersebut, penelitian ini dilakukan untuk mengetahui pengaruh konseling obat terhadap kepatuhan terapi pasien CHF di IRNA Jantung RSUP DR. M. Djamil Padang.

\section{METODOLOGI}

\section{Jenis Penelitian}

Jenis penelitian ini adalah prospektif quasi-eksperimental, dengan konsep one group pretest-posttest design. Desain penelitian ini bertujuan untuk mengetahui pengaruh intervensi yang diberikan pada selang waktu tertentu kepada kelompok objek yang diteliti, dengan membandingkan hasil pemeriksaan akhir (posttest) terhadap hasil pemeriksaan awal (pretest) [11,12].

\section{Populasi dan Sampel}

Populasi target penelitian ini adalah pasien CHF, sedangkan populasi terjangkau dibatasi pada pasien CHF di IRNA Jantung RSUP DR. M. Djamil Padang. Teknik pengambilan sampel yang digunakan adalah purposive sampling, yaitu penentuan sampel dengan pertimbangan khusus (kriteria inklusi dan eksklusi) sehingga layak dijadikan sampel. Kriteria inklusi ( $\mathrm{n}=123$ ) meliputi semua pasien di IRNA Jantung RSUP DR. M. Djamil Padang yang didiagnosis CHF. Kriteria eksklusi $(n=48)$. Sebanyak 25 orang pasien drop out karena dirawat kurang dari 10 hari.

\section{Tempat dan Waktu Pelaksanaan}

Penelitian ini dilakukan selama bulan Maret - Desember 2014 di IRNA Jantung RSUP DR. M. Djamil Padang.

\section{Instrumen Penelitian}

Instrumen yang digunakan adalah kuesioner pretest-posttest aspek pengetahuan dan perilaku, lembar MLHFQ, lembar persetujuan pasien, protokol konseling obat, modul $\mathrm{CHF}$, modul obat $\mathrm{CHF}$, kartu minum obat mandiri, tabel induk data responden, tabel induk untuk skor pengetahuan, tabel induk untuk skor perilaku, dan tabel induk untuk pill count.

\section{Sumber Data}

Sumber data pada penelitian ini, yaitu data primer berupa kuesioner, rekam medik pasien, dan hasil wawancara yang langsung dilakukan pada objek penelitian.

\section{Prosedur Pengumpulan Data}

Pasien yang memenuhi kriteria inklusi (calon responden) dijelaskan mengenai tujuan konseling 
dan penelitian, lalu diminta kesediaannya untuk menjadi responden. Kemudian pada saat pasien selesai melakukan pemeriksaan dan telah diberikan resep, dilakukan pretest untuk mengetahui pengetahuan, perilaku, dan MLHFQ pasien dengan wawancara dan menggunakan lembar kuesioner, setelah itu dilakukan konseling obat dengan menggunakan modul, brosur obat, dan kartu minum obat mandiri. Sepuluh hari kemudian, dilakukan posttest untuk menilai pengetahuan, perilaku, dan kualitas hidup pasien setelah konseling obat. Selain itu, juga dilakukan penghitungan sisa obat pasien (pill count) untuk menilai \% kepatuhan [13].

Data yang diperoleh kemudian direkapitulasi dalam tabel induk untuk dianalisis.

\section{Analisis Data}

Analisis data dalam penelitian ini dilakukan secara bertahap [14]. Crosstab, Chi-Square,
Paired-sample T-test, Pearson Product Moment dan Uji regresi linear berganda,

\section{HASIL DAN DISKUSI}

Hasil

a. Karakteristik Demografi Pasien

Dari penelitian ini, diperoleh data demografi pasien seperti pada Tabel 1 .

b. Pengaruh Konseling Obat terhadap Pengetahuan Pasien

Untuk melihat pengaruh konseling obat terhadap pengetahuan pasien, terlebih dahulu dilihat perbedaan antara skor pengetahuan pasien sebelum dan setelah dilakukan konseling dengan menggunakan uji Paired-Samples T Test seperti pada Tabel 2. Nilai rerata skor pengetahuan setelah pemberian konseling lebih tinggi daripada

Tabel 1. Distribusi Frekuensi Karakteristik Demografi Pasien

\begin{tabular}{|c|c|c|c|}
\hline No. & Kategori & Frekuensi & Persentase (\%) \\
\hline \multirow[t]{4}{*}{1.} & Usia & 65,33 & Baik \\
\hline & $36-45$ tahun & 8 & 16 \\
\hline & $46-55$ tahun & 19 & 38 \\
\hline & $56-65$ tahun & 23 & 46 \\
\hline \multirow[t]{3}{*}{2.} & Jenis Kelamin & 82,76 & Sangat baik \\
\hline & Laki-laki & 33 & 76 \\
\hline & Perempuan & 17 & 34 \\
\hline \multirow[t]{5}{*}{3.} & Pendidikan & 84 & Sangat baik \\
\hline & SD & 2 & 4 \\
\hline & SLTP & 4 & 8 \\
\hline & SLTA & 31 & 62 \\
\hline & Perguruan tinggi & 13 & 26 \\
\hline \multirow[t]{6}{*}{4.} & Lama menderita $\mathrm{CHF}$ & & \\
\hline & $<1$ tahun & 1 & 2 \\
\hline & $1-5$ tahun & 3 & 6 \\
\hline & $5-10$ tahun & 10 & 20 \\
\hline & 11-15 tahun & 13 & 26 \\
\hline & $>15$ tahun & 13 & 46 \\
\hline
\end{tabular}


Tabel 2. Hasil Paired-Samples T Test Data Skor Pengetahuan Sebelum dan Setelah Konseling Obat

\begin{tabular}{|c|c|c|c|c|c|c|}
\hline Data & Rerata & $S D$ & Korelasi & Nilait & $D f$ & Sign \\
\hline Skor Pretest & 20 & 5,1 & - & - & - & - \\
\hline Skor Posttest & 40,2 & 4,41 & - & - & - & - \\
\hline Korelasi Skor Posttest-Pretest & - & - & 0,986 & - & - & 0,000 \\
\hline Perbedaan Skor Posttest-Pretest & $-19,480$ & 1,092 & - & -126 & 49 & 0,000 \\
\hline
\end{tabular}

sebelum konseling, dengan nilai thitung -126,086 dan P-value lebih kecil dari 0,05 (0,000 < 0,05). Dengan demikian, dapat disimpulkan bahwa pemberian konseling obat dapat meningkatkan pengetahuan pasien CHF secara signifikan.

Selanjutnya, pengaruh konseling obat terhadap pengetahuan pasien dianalisis dengan uji regresi linear sederhana sebagaimana pada Tabel 3.

Nilai thitung 40,891 dengan koefisien P-value yang diperoleh lebih kecil dari 0,05. Dengan demikian, dapat disimpulkan bahwa regresi dan hubungan konseling obat terhadap pengetahuan bernilai signifikan.

c. Pengaruh Konseling Obat terhadap Perilaku Pasien

Pengaruh konseling obat terhadap perilaku pasien antara skor pengetahuan pasien sebelum dan setelah dilakukan konseling dengan menggunakan uji Paired-Samples T Test seperti yang tertera pada Tabel 4.

Nilai rerata skor perilaku setelah pemberian konseling lebih rendah daripada sebelum konseling.

Tabel 3. Hasil Uji Regresi Sederhana Pengaruh Konseling Obat terhadap Pengetahuan Pasien

\begin{tabular}{|c|c|c|c|c|c|c|}
\hline Variabel Terikat & Variabel Bebas & $B$ & $T$ & Sig. & $D f$ & Sign \\
\hline Pengetahuan Posttest & $\begin{array}{c}\text { Pengetahuan } \\
\text { Pretest }\end{array}$ & 0,844 & 40,891 & 0,000 & - & - \\
\hline $\mathrm{R}$ & 0,986 & & - & - & - & - \\
\hline $\mathrm{R} 2$ & 0,972 & & 0,986 & - & - & 0,000 \\
\hline Adjusted R2 & 0,972 & & - & -126 & 49 & 0,000 \\
\hline F hitung & 1672.057 & & & & & \\
\hline Signifikansi & 0,000 & & & & & \\
\hline
\end{tabular}

Tabel 4. Hasil Paired-Samples T Test Data Skor Perilaku Sebelum dan Setelah Konseling Obat

\begin{tabular}{|c|c|c|c|c|c|c|}
\hline Data & Rerata & $S D$ & Korelasi & Nilait & $D f$ & Sign. \\
\hline Skor Pretest & 5,720 & 1,959 & - & - & - & - \\
\hline Skor Posttest & 0,740 & 0,481 & - & - & - & - \\
\hline $\begin{array}{c}\text { Korelasi Skor Posttest- } \\
\text { Pretest }\end{array}$ & - & - & 0,884 & - & - & 0,000 \\
\hline $\begin{array}{c}\text { Perbedaan Skor Posttest- } \\
\text { Pretest }\end{array}$ & 4,980 & 1,550 & - & 22,718 & 49 & 0,000 \\
\hline F hitung & 1672.057 & & & & & \\
\hline Signifikansi & 0,000 & & & & & \\
\hline
\end{tabular}


Nilai thitung rerata peningkatan tersebut 22,718 dengan P-value lebih kecil dari 0,05 $(0,000<0,05)$ yang berarti signifikan. Hal ini menunjukkan bahwa konseling obat yang diberikan secara signifikan dapat meningkatkan perilaku terapi pasien.

d. Pengaruh Konseling Obat terhadap Kualitas Hidup Pasien

Pengaruh konseling obat terhadap Kualitas Hidup pasien dilihat dengan menggunakan uji Paired-Samples T Test sebagaimana yang tertera pada Tabel 5 .

Nilai $r$ hitung yang diperoleh sebesar 0,925 dengan nilai signifikansi $0,00<0,05$. Hal ini menunjukkan bahwa skor posttest pengetahuan dan skor posttest perilaku tersebut berkorelasi signifikan.

f. Pengaruh Pengetahuan dan Perilaku terhadap MLHFQ Pasien
Untuk melihat pengaruh pengetahuan dan perilaku pasien terhadap MLHFQ setelah pemberian konseling obat, dilakukan uji regresi linear ganda seperti yang tertera pada Tabel 6 .

Nilai thitung yang diperoleh sebesar -9,555 dan -3,097 dengan P-value yang diperoleh lebih kecil dari 0,05 (0,000 dan 0,003 < 0,05). Sehingga dapat disimpulkan bahwa regresi dan koefisien korelasi bernilai signifikan, sehingga pengetahuan dan perilaku dapat digunakan untuk memprediksi MLHFQ pasien.

\section{g. Pill Count}

Berdasarkan Tabel 7, dapat diketahui bahwa sebagian besar pasien memiliki tingkat kepatuhan yang sempurna terhadap terapi yang diterima, yaitu sebanyak 38 orang (76\%).

\section{Pembahasan}

a. Karakteristik Demografi Pasien

Tabel 5. Hasil Paired-Samples T Test Data Skor MLHFQ Sebelum dan Setelah Konseling Obat

\begin{tabular}{|c|c|c|c|c|c|c|}
\hline Data & Rerata & $S D$ & Nilai Korelasi & Nilait & $D f$ & Sign. \\
\hline Skor Pretest & 95,48 & 10,076 & - & - & - & - \\
\hline Skor Posttest & 46,38 & 11,084 & - & - & - & - \\
\hline Korelasi Skor Posttest-Pretest & - & - & 0,940 & - & - & 0,000 \\
\hline Perbedaan Skor Posttest-Pretest & 49,100 & 3,792 & - & 91,564 & 49 & 0,000 \\
\hline F hitung & 1672.057 & & & & & \\
\hline Signifikansi & 0,000 & & & & & \\
\hline
\end{tabular}

Tabel 6. Hasil Uji Regresi Linear Ganda Pengaruh Pengetahuan dan Perilaku terhadap MLHFQ Pasien

\begin{tabular}{|c|c|c|c|c|c|c|}
\hline Variabel Terikat & Variabel Bebas & $B$ & $T$ & Sign & $D f$ & Sign. \\
\hline CAT Posttest & Pengetahuan Posttest & $-3,362$ & $-9,555$ & 0,000 & - & - \\
\hline & Perilaku Posttest & $-9,989$ & $-3,097$ & 0,00 & - & - \\
\hline $\mathrm{R}$ & 0,944 & & 0,884 & - & - & 0,000 \\
\hline $\mathrm{R} 2$ & 0,891 & & - & 22,718 & 49 & 0,000 \\
\hline Adjusted R2 & 0,886 & & & & & \\
\hline $\mathrm{F}$ hitung & 191,336 & & & & & \\
\hline Signifikansi & 0,000 & & & & & \\
\hline
\end{tabular}


Tabel 7. Hasil Perhitungan Pill Count Pasien

\begin{tabular}{|c|c|c|}
\hline $\begin{array}{c}\text { Nilai Persentase } \\
\text { Kepatuhan }\end{array}$ & Frekuensi & Persentase \\
\hline $85,00 \%$ & 2 & $4 \%$ \\
\hline $94,44 \%$ & 2 & $4 \%$ \\
\hline $95,00 \%$ & 1 & $2 \%$ \\
\hline $95,19 \%$ & 1 & $2 \%$ \\
\hline $95,56 \%$ & 1 & $2 \%$ \\
\hline $96,67 \%$ & 1 & $2 \%$ \\
\hline $97,04 \%$ & 1 & $2 \%$ \\
\hline $97,78 \%$ & 1 & $2 \%$ \\
\hline $98,61 \%$ & 1 & $2 \%$ \\
\hline $99,26 \%$ & 1 & $2 \%$ \\
\hline $100,00 \%$ & 38 & $76 \%$ \\
\hline Jumlah & 50 & $100,00 \%$ \\
\hline
\end{tabular}

Dari penelitian yang telah dilakukan terhadap 50 orang pasien CHF di IRNA Jantung RSUP DR. M. Djamil Padang, diamati empat karakteristik demografi pasien, yaitu usia, jenis kelamin, latar belakang pendidikan terakhir, dan lama menderita CHF. Dari data distribusi frekuensi kelompok usia pasien, diketahui terbanyak berada di kategori kelompok 55-65 tahun (46\%). Hal ini disebabkan oleh progresivitas $\mathrm{CHF}$ yang lambat sehingga CHF sering didiagnosis pada pasien usia usia 40 tahun ke atas dengan jumlah pasien terbanyak berada pada usia 55 tahun ke atas [15].

Dari data distribusi frekuensi jenis kelamin pasien, diketahui bahwa bahwa mayoritas pasien (66\%) berjenis kelamin laki-laki. Hal ini sesuai dengan literatur [15] dan terkait dengan penyakit jantung, laki-laki yang lebih banyak dibandingkan pada wanita. Dan literature lain [16] menyebutkan bahwa pada wanita resiko penyakit jantung sekitar 10-15 tahun lebih lambat daripada pria dan resiko meningkat secara drastis setelah menopause.

Data distribusi frekuensi pendidikan pasien, kelompok pasien SLTA memiliki jumlah pasien terbanyak (62\%) dan Perguruan Tinggi (26\%). Hal ini terkait dengan latar belakang lingkungan pasien, terutama lingkungan pekerjaan. Hal ini sesuai literatur yang menyatakan semakin tinggi pendidikan maka semakin tinggi kepatuhan dan kualitas hidup pasien [5,17].

Dari data frekuensi lama menderita $\mathrm{CHF}$, sebanyak $46 \%$ pasien menderita CHF selama $>15$ tahun, sedangkan sisanya berada pada kategori 10-15 tahun (26\%), kategori 5-10 tahun (20\%), kategori 1-5 tahun (6\%) dan kategori $<1$ tahun $(2 \%)$. Banyaknya pasien pada kategori $>15$ tahun tersebut dipengaruhi oleh lambatnya onset gejala CHF yang timbul. Selain itu, rendahnya kesadaran terhadap kesehatan menjadi alasan lainnya. Pasien pada awalnya menganggap keluhan yang dimiliki bukan hal yang serius dan membahayakan sehingga mereka kurang inisiatif untuk memeriksakan kesehatan. Pada saat keluhan yang dirasakan sudah sangat menganggu aktivitas sehari-hari, mereka baru memeriksakan ke dokter dan didiagnosis CHF dengan derajat berat.

b. Pengaruh Konseling terhadap Pengetahuan Pasien

Pada penelitian ini diketahui bahwa bahwa konseling obat yang diberikan dapat meningkatkan pengetahuan pasien secara signifikan. Peningkatan pengetahuan tersebut dipengaruhi oleh konseling obat sebesar 34,1\%, sedangkan $65,9 \%$ lainnya dipengaruhi oleh variabel lain yang tidak diteliti.

Peningkatan skor pengetahuan yang terjadi setelah konseling menunjukkan bahwa tujuan konseling tercapai. Sesuai dengan teori edukasi yang menyatakan bahwa konseling harus bertujuan untuk mendidik pasien sehingga pengetahuan pasien mengenai obat akan meningkat dan hal ini akan mendorong pada perubahan perilaku. Melalui konseling (disertai dengan penjelasan yang memadai), asumsi dan perilaku pasien yang salah akan dapat diperbaiki/dikoreksi. Peningkatan skor pengetahuan setelah diberikan konseling menunjukkan bahwa konseling merupakan metode 
yang sesuai untuk meningkatkan pengetahuan, sesuai dengan teori yang menyatakan bahwa untuk meningkatkan pengetahuan seseorang dapat digunakan dengan cara ceramah, membaca, dan konseling [5].

Konseling sangat berperan penting dalam meningkatkan kepatuhan pasien terhadap pengobatan. Konseling merupakan metode yang sesuai dalam meningkatkan pengetahuan pasien, karena konseling merupakan komunikasi dua arah yang sistematis antara pasien dengan farmasis. Konseling terbentuk dari dua unsur yaitu konsultasi dan edukasi, dimana dengan konsultasi pasien mengutarakan semua kesulitannnya dalam menjalani pengobatan, dan dengan edukasi seorang farmasis dapat membantu dalam menyelesaikan masalah pasien tersebut [5].

c. Pengaruh Konseling terhadap Perilaku Pasien

Berdasarkan hasil Paired-Samples $T$ Test yang dilakukan, diketahui bahwa konseling yang diberikan dapat meningkatkan perilaku terapi pasien secara signifikan. Peningkatan perilaku yang terjadi setelah konseling menunjukkan bahwa informasi yang didapatkan setelah konseling dapat meningkatkan pengetahuan pasien yang berdampak positif pada perubahan perilaku pasien terhadap penyakit dan pengobatannya.

Banyak pasien yang memiliki persepsi bahwa obat itu adalah racun dan apabila diminum setiap hari, obat tersebut akan menumpuk di dalam tubuh dan berakibat buruk. Untuk itu konselor harus menekankan bahwa obat CHF itu aman bagi tubuh dan akan dikeluarkan secara berkala melalui urin maupun feses, bahkan apabila tidak dikonsumsi, obat tersebut justru akan lebih berbahaya bagi tubuh mereka. Penyakit yang mereka derita akan semakin mengalami perburukan [18].

Faktor-faktor luar yang bisa memengaruhi persepsi individu terhadap ancaman penyakit dan bertindak sebagai pemicu tindakan misalnya adalah artikel atau kampanye di media massa, nasehat dari orang lain dan penyakit yang mirip diderita oleh orang terdekat bisa memicu tindakan [19].

\section{d. Pengaruh Konseling terhadap MLHFQ Pasien}

Berdasarkan hasil yang diperoleh, diketahui bahwa adanya penurunan skor MLHFQ setelah konseling. Penurunan MLHFQ tersebut berarti terjadi perbaikan kondisi dan peningkatan kualitas hidup pasien. Dengan demikian, dapat disimpulkan bahwa pemberian konseling obat dapat meningkatkan kualitas hidup pasien yang dinilai dari MLHFQ.

\section{e. Hubungan Pengetahuan terhadap Perilaku}

Hasil penelitian ini menunjukkan bahwa terdapat hubungan yang signifikan antara pengetahuan terhadap perilaku pasien setelah dilakukan konseling dan berdasarkan hasil analisis statistik diperoleh hubungan yang signifikan antara pengetahuan terhadap perilaku yang menunjukkan bahwa konseling mampu memberikan perubahan perilaku sebagaimana tujuan pemberian konseling.

f. Pengaruh Pengetahuan dan Perilaku terhadap terhadap MLHFQ Pasien

Hasil uji regresi linear berganda menunjukkan bahwa skor posttest pengetahuan dan perilaku pasien secara besama-sama memberikan kontribusi terhadap skor posttest pengetahuan sebesar $88,6 \%$, sedangkan sisanya dipengaruhi oleh variabel lain yang tidak diteliti. Hal ini sejalan dengan penjelasan sebelumnya bahwa banyak faktor lain yang memengaruhi MLHFQ pasien, terutama derajat berat penyakit dan pembatasan aktivitas sehari-hari.

\section{g. Pill Count Pasien}

Hasil perhitungan Pill Count digunakan untuk menilai besar kepatuhan pasien berdasarkan masing-masing obat yang didapatkan. Metode 
Pill Count dilakukan dengan menghitung jumlah sisa obat yang dimiliki pasien selama terapi pada periode tertentu (dilakukan pada pertemuan kedua di IRNA Jantung RSUP DR. M. Djamil) Padang. Berdasarkan hasil pill count yang dilakukan, dapat diketahui bahwa sebagian besar pasien memiliki tingkat kepatuhan yang sangat baik (100\%) terhadap terapi yang diterima, yaitu sebanyak 38 orang $(76 \%)$.

Pada penelitian ini, Pill Count hanya dilakukan terhadap obat-obat untuk terapi pemeliharaan. Obat-obat yang berfungsi sebagai penanganan serangan mendadak tidak dimasukkan karena digunakan bila perlu (yang tercantum dalam resep). Obat yang dimaksud adalah isosorbid dinitrat yang pada beberapa pasien digunakan bila perlu.

Berdasarkan hasil penelitian ini, dapat dipahami pentingnya peran farmasis dalam memberikan informasi dan edukasi terapi melalui konseling obat terhadap pasien $\mathrm{CHF}$ sehingga kepatuhan terapi pasien dapat lebih ditingkatkan.

\section{KESIMPULAN}

Berdasarkan penelitian yang dilakukan, diperoleh kesimpulan sebagai berikut:

a. Ada pengaruh positif (peningkatan) yang signifikan akibat pemberian konseling obat terhadap pengetahuan pasien tentang penyakit dan terapi obat CHF. Konseling obat dapat meningkatkan pengetahuan pasien sebesar 97,2\%.

b. Ada pengaruh positif (peningkatan) yang signifikan akibat pemberian konseling obat terhadap perilaku pasien dalam menjalani terapi obat CHF.

c. Ada pengaruh positif (peningkatan) yang signifikan akibat pemberian konseling obat terhadap perubahan kualitas hidup pasien yang dinilai melalui nilai MLHFQ pasien CHF.

\section{DAFTAR PUSTAKA}

1. Marcum, J.L. (2008). When The Heart Attack. USA : Tyndale House Publishers.

2. Delima, Laurentia, M., \& Hadi, S. (2009). Prevalence and Determinants Heart Disease in Indonesia. Jakarta: Buletin Peneliti Kesehatan, 37(3):142-159.

3. Panella, M., Marchisio, S., Demarchi, M.L., Manzoli, L., Di Stanislo, F. (2009). Reduced in Hospital Mortality for Heart Failure with Clinical Pathways: The Results of a Cluster Randomized Controlled Trial. 18(5):369-73, diakses pada 6 Januari 203 dari http://www.ncbi.nlm.nih.gov/pubmed/19812099.

4. Schnipper, J.L., Kirwin, J.L., Cotugno, M.C., Wahlstrom, S.A., Brown, B.A., Tarvin, E., Kachalia, A., Horng, M., Roy, C.L., McKean, S.C., Bates, D.W. (2006). Role of Pharmacist Counseling in Preventing Adverse Drug Events After Hospitalization. USA: Archieves of Internal Medicine.Vol 166:565-571

5. Rantucci, M.J. (2007). Komunikasi apoteker-pasien: panduan konseling pasien. 2nd Ed. Penerjemah A.N. Sani. Jakarta: Penerbit Buku Kedokteran EGC.

6. Sin, D.D., McAlister, F.A., \& Man, S.F. (2003). Contemporary management of chronic obstructive pulmonary disease: scientific review. JAMA 2003;290:2301012.

7. World Health Organization Media Center. (2013). Chronic obstructive pulmonary disease (COPD). Accessed on May 2013. Available at: http://www.who.int/en/2013/copd.pdf.

8. DiMatteo, M.R. (2004). Variations in patients' adherence to medical recommendations: a quantitative review of 50 years of research. Med Care 2004;42:200-209.

9. Menteri Kesehatan RI. (2004). Keputusan Menteri Kesehatan Republik Indonesia Nomor 1197/MENKES/SK/X/2004 tentang Standar Pelayanan Farmasi di Rumah Sakit. Jakarta: Departemen Kesehatan RI.

10. Siregar, C.J.P., \& Kumolosasi, E. (2006). Farmasi klinik teori dan penerapan, Jakarta: Penerbit Buku Kedokteran EGC.

11. Campbell, D.T., \& Ctanley, J.C. (1963). Experimental and QuasiExperimental Designs for Research. Chicago: Rand McNally.

12. Widiyanto, M.A. (2013). Statistika terapan: konsep dan aplikasi SPSS/LISREL dalam penelitian pendidikan, psikologi, dan ilmu sosial lainnya. Jakarta: Elex Media Komputindo.

13. Jasti, Sunita. (2005). Pill count adherence to prenatal multivitamin/mineral supplement use among low-income women. The American Society Journal of Nutritions, 135, 1093-1101.

14. Sugiyono. (2007). Metode Penelitian Administrasi. Bandung: Alfabeta.

15. Ulfa, A. (2000). Gejala Awal dan Deteksi Dini Penyakit Jantung Koroner. Artikel IImiah Pd-PERSI. Jakarta.

16. Stangl, V. (2002). Coronary Atherogenic Risk Factors in Women. Eur Heart J. 23:1738-1752.

17. Basuki, Endang. (2009). Konseling medik: kunci menuju kepatuhan pasien. Majalah Kedokteran Indonesia 2009;59:2.

18. Wells, B.G., Dipiro, J.T., Schwinghammer, T.L., \& Hamilta, C.W. (2006). Pharmacotherapy handbook. 6th Ed. Cetakan VI. New York: The McGraw Hill Co.

19. Borbeau, J., \& Bartlett, S.J. (2008). Patient adherence in COPD. Thorax 2008;63:831-838. 